\title{
PENANAMAN NILAI-NILAI KARAKTER ISLAM MODERAT PADA ANAK USIA DINI DI RA DWP IAIN PALU
}

\author{
Gusnarib Wahab \\ Dosen Fakultas Tarbiyah dan Ilmu Keguruan Institut Agama Islam Negeri Palu
}

\begin{abstract}
ABSTRAK
Penelitian ini bertolak dari rumusan masalah yakni bagaimana bentuk implementasi penanaman nilai-nilai karakter Islam moderat melalui sosialisasi dan pembelajaran pada anak usia dini di RA/TK DWP IAIN Palu, faktor pendukung dan penghambat serta implikasi dari implementasi penanaman nilai nilai karater Islam moderat melalui sosialisasi dan pembelajaran pada anak usia dini di RA DWP IAIN Palu. Metode penelitian yang digunakan penelitian kualitatif dengan pendekatan penelitian tindakan kelas dengan mendeskripsikan tentang proses implementasi penanaman nilai-nilai karakter Islam Moderat melalui sosialisasi dan pembelajaran pada anak usia dini. Selanjutnya pengumpulan data dilakukan dengan cara observasi, wawancara dan dokumentasi. Teknik analisa data yang digunakan adalah reduksi data, penyajian data dan verifikasi data menggunakan skala penilaian indicator karakter dengan mengukur pada skala sikap : BT (Belum Terlihat), MT (Mulai terlihat), MB (Mulai berkembang), MK (Sudah Menjadi Kebiasaan dan sudah Membudaya). Hasil penelitian menunjukkan bahwa berdasarkan analisa dan hasil pembahasan terhadap Implementasi penanaman nilai nilai karakter islam moderat, dari aspek Kesetaraan, Pembebasan, Toleransi, Kemanusiaan, Pluralisme,Kemanusiaan, Sensitifitas, dan Non Deskriminatif. Oleh karena itu dapat disimpulkan bahwa penanaman nilai nilai karakter Islam moderat pada anak usia dini di RA DWP IAIN Palu sudah terlaksana namun belum dapat terukur sesuai harapan yaitu pada indicator tertinggi yaitu, Sudah menjadi kebiasaan dan sudah membudaya (MK).
\end{abstract}

Kata Kunci : Nilai Karakter, Islam Moderat, Anak usia dini.

\section{PENDAHULUAN}

Pembelajaran yang awal mulanya diistilakan dengan kata mengajar yang kini dengan perkembangan dalam dunia pendidikan dan pembelajaran berubah peristilahan dan nomen kelatur menjadi pembelajaran, pembelajaran berasal dari kata teach atau mengajar berasal dari bahasa inggeris kuno, yaitu taecan. kuno teacan berarti to teach (mengajar). Dengan demikian, to dan teach secara historis memiliki keterkaitan. To teach ( mengajar) dilihat dari asal katanya berarti memperlihatkan sesuatu kepada seseorang melalui tanda atau simbol. Sejak tahun 1500-an definisi mengajar (teaching) mengalami perkembangan terus menerus. Secara deskriptif mengajar diartikan sebagai proses menyampaikan informasi atau pengetahuan dari pendidik kepada peserta didik. Proses penyampaian itu sering juga dianggap sebagai proses mentransfer ilmu 
pengetahuan dan nilai didikan (transfer of knowledge and transfer of value) Smit juga mengurai bahwa, mengajarkan pengetahuan atau keterampilan (teaching is imparting knowledge or skill) pandangan (Sanjaya Wina, 2008 ). Pembelajaran nilai nilai karakter dengan pendekatan nilai nilai ke Islaman sangat dibutuhkan dewasa ini mengingat dan memotret model dan bentuk pergaulan, lingkungan komunikasi, serta sikap dan perilaku peserta didik khususnya di RA DWP IAIN Palu (anak anak) penting untuk terperhatikan mperihatinkan jika kita memotret secara utuh, menjadi tanggung jawab kita para pendidik, orang tua di rumah, tokoh masyarakat demikian pula para Stakeholder, berupaya mencari dan memformulasikan teknik dan model model pembelajaran nilai nilai karakters Islam moderat sehingga ketimpangan sosial dan permasalahan pendidikan dapat terurai dan tersambung utaskan pada titik benang merahnya.

Berdasarkan pengertian di atas, maka ada tiga hal penting yang menjadi karakteristik suatu sistem. Pertama, setiap sistem pasti memiliki tujuan, tujuan merupakan ciri utama sebuah sistem, tujuan merupakan arah yang harus dicapai oleh suatu pergerakan sistem. Kedua, Sistem selalu mengandung suatu proses dan proses adalah rangkaian kegiatan. Kegiatan diarahkan untuk mencapai tujuan, semakin kompleks suatu tujuan maka semakin rumit juga proses kegiatan.Ketiga. Proses kegiatan dalam suatu sistem selalu melibatkan sama dan memanfaatkan berbagai komponen atau unsur unsur tertentu.

Pandangan dari konsep pembelajaran yang ditawarkan melalui studi ini dua kolaborasi sistem pembelajaran yang berbeda Zaman namun berpandanga dan berhaluan sama yang memiliki banyak kesamaan,dalam aplikasi dan implementasi suatu pembelajaran yang dinamakan sistem pembelajaran "Among” dan sistem pembelajaran "Konstruktivisme" (kontekstual) konsep pembelajaran " Piaget" kedua sistem pembelajaran ini; Sangat mengapreasi arti pentingnya pengalaman atau perilaku awal peserta didik ( anak anak) ,esensinya menggali potensi peserta didik dengan memberikan kesempatan pada aspek kebebasan untuk menumbuhkan kreatitas dan inovasi positif serta kebebasan berkarya, bernyanyi dan bermain demikian pula berpendapat, (Inquiry and Discovery) penulis mencoba melihat irisan kedua sistem pembelajaran yang sangat menghargai dan menghormati eksistensi setiap individu (peserta didik atau anak anak ) sebagai pebelajar (Piaget 1969).

Berdasar kedua sistem pembelajaran tersebut penulis melakukan studi penjajakan dan penelitian tentang kelayakan teori, konsep dan sistem pembelajaan Among ( konsep awal pendidikan nasional) dan konstruktivisme( konsep kontektual learning), memoteret, mengamati serta mengimplementasikan bentukan penanaman nilai karakter dilihat dan ditinjau dari nilai nilai islam moderat, gambaran dan konsep dasar nilai nilai karakter diintegrasikan para guru menurut pandangan konsep teori pendidikan anak usia dini. 
Berdasarkan hasil pengamatan yang dilakukan peneliti di RA DWP IAIN Palu peneliti menemukan beberapa masalah, dalam hal bagaimana guru melakukan penanaman dan pengintegrasian nilai nilai karakter islam moderat pada pembelajaran masih ditemukan ketidak singkronan antara nilai nilai karakter yang ingin diintegrasikan dengan materi yang diajarkan dengan sarana prasarana yang tersedia, pada dasarnya kemampuan guru mengurai nilai nilai karakter islam, esensi dan makna suatu pembelajaran cukup baik terlihat tingginya animo guru datang dan melakukan pembelajaran, walaupun enam bulan yang lalu di RA DWP IAIN Palu pasca gempa bumi hampir tidak terihat aktivitas pembelajaran itu berlangsung namun enam bulan terakhir setelah gempa melanda Palu dan khususnya kampus IAIN yang nota benenya RA DWP IAIN Palu juga berada dalam satu area kampus IAIN Palu sehingga ikut juga tersapu tsunami namun ketika peneliti melakukan studi penjajaakan atau pengamatan awal dengan sarana prasarana serta area yang dimiliki RA DWP IAIN Palu, sangat sempit namun amatan peneliti berdasarkan informasi dari kepala sekolah dan para guru dan pengelolah motivasi dan animo orang tua sudah mulai berangsur memilih RA DWP IAIN Palu, amatan dan temuan data periodic dan perkembangan peserta didik mulai mengalami kenaikan atau meningkat kepercayaan untuk menyekolahkan putra putrinya di RA DWP IAIN Palu sudah seperti sedia kala sebelum bencana sunami melanda kota Palu dan sekitarnya pada tanggal 28 oktober 2018.

Pandangan peneliti hal ini disebabkan masih kurangnya pengajar (guru) serta pengelolah pada RA DWP IAIN Palu dan belum terintegrasinya secara maksimal nilai nilai karakter Islam moderat pada anak anak usia dini perlu peningkatan penguasaan materi, metode dan pendekatan belajar serta perlunya guru mencari pengayaan dan memperkaya media pembelajaran dan permainan edukatif yang berkaitan dengan materi berdoa, bernyanyi, bermain dan berkarya yang diajarkan sesuai materi nilai nilai karakter islam moderat, nilai nilai karakter kearifan local serta nilai nilai karakter kearifan Qur"ani.

Merujuk pada pentingnya penanaman nilai nilai karakter islam moderat lebih dini diperkenalkan pada anak usia dini tentang pentingnya memelihara sifat "toleransi" antar umat beragama, pentinya saling menghargai perbedaan dan menghormati kemajemukan dalam berkehidupan, beragama maupun bersosial budaya, penting memelihara "kesetaraan" atau" kesederajatan" tidak boleh ada perbedaan klasifikasi social dan strata social perlu dipelihara dalam kehidupan sehari hari, pentinya kita memiliki sikap "sensitive" memupuk dan memelihara sifat dan sikap peduli dan "kepekaan" terhadap sesama hidup baik itu sesama manusia demikian pula terhadap mahluk hewan dan tumbuhan kita harus tetap mempertahankan dan memelihara eksistensinya dimuka bumi karna kita manusia adalah mahluk termuliah disisi Allah,pentinya kita memelihara sifat tidak membeda bedakan orang lain atau tidak "diskriminatif" dalam berbagai hal dalam kehidupan individu, social dan budaya semua orang itu kita dapat bekerjasama mencapai tujuan tidak boleh ada 
perasaan tidak bersahabat atau tidak sama karna dimata Allah dan dimata hukum kita sama mengapa dimata manusia harus berbeda jadi tidak boleh kita mengibarkan sifat dan sikap diskriminasi atu sifat mengklaim kelompok tertentu semua kita bersaudara, pentingnya kita memelihara sifat dan sikap memberi ruang dan " kesempatan" yang sama pada semua orang memberikan "kebebasan" dan kesempatan setiap individu untuk berpendapat ruang public yang bebas (Pri public spehare) dan bebas berkarya sesuai potensi bakat minatnya tiap individu, tidak boleh dibatasi hak hak orang lain, tentang arti pentingnya kita memelihara sifat "kemanusiaan", sifat dan sikap menghargai semua orang dan ciptaan Allah dengan memupuk dan memelihara sifat sifat dan sikap terpuji menghargai dan menghormati kemanusiaan setiap orang adalah perbuatan muliah disisi Allah.

Pada dasarnya semua sifat dan sikap dapat kita jabarkan dalam kehidupan kita sehari hari dan dapat kita jadikan pedoman dalam berkehidupan beragama berbangsa dan bernegara, sebagai warga Negara yang baik dan bertanggungjawab harus tunduk dan patuh terhadap aturan kenegaraan dimanapun Negara dia bertempat tinggal dalam beraktifitas, demikian gambaran arti pentingnya penanaman nilai nilai karakter nilai nilai karakter islam moderat agar anak kelak dapat hidup di tengah masyarakat dengan memiliki prinsip prinsip mendasar tergambar diatas, tentang arti pentingnya mengetahui dan memahami nilai nilai kearifan local baik itu local wisdom maupun local genius bahkan in the genius local kearifan lokal menanankan sifat dan sikap kepada anak lebih dini pada anak usia dini pentingnya memelihara budaya bangsanya, mengenal tatakrama adat istidatnya, petuah petuah, nyanyian nyanyian lagu dan pesan moral dalam acara adat istidat acara suka maupun duka, pantun berbalas ketika ada pesta adat perkawinan, acara aqikah, acara duka demikian pula acara acara syukuran dan pengobatan(baliah) sehingga anak anak lebih dini memahami semua itu, arti makna pentingnya berdoa (local wisdom), anak anak usia dini lebih dini mengetahui dan memahami apa arti pentinya symbol warna tertentu pada setiap daerah yang memegang dan menjalankan adat, apa itu perangkat adat dalam acara pesta suka maupun duka, demikian pula pada acara sukuran maupun pengobatan atau Baliah atau persyaratan adat sambulugana misalkan dalam hal menghambur beras kuning ketika ada pengantin, adat tahu penting, barsanji dan acara aqikah, ada pemasangan bendera orang orangan berwarnah kuning yang disebut ulah ulah, apa makna toru, demikian pula perangkat adat sambuluh gana dan masih banyak lainnya, pentingnya tarian lagu dan nyanyian dan pakaian adat dipelihara dan dilestarikan karna itu merupakan kekayaan budaya suku bangsa ( local genius) arti pentinya peninggalan peninggalan bersejarah arti kekeluargaahargai dan menghormati para leluhur dan pahlawan serta para suhadah, mengapa harus berziarah atau menziarahi kuburan keluarga orang tua kita yang sudah wafat dan demikian pula ada banyak hal yang dianggap tabuh dan memiliki tingkat kesakralan yang tinggi pada orang tertentu pada suku tertentu pada cara adat tertentu hal sepeti itu biasanya disebut (in the genius) dan serta arti pentingnya 
mentahui dan memahami serta mempraktekkan dalam kehidupan nilai nilai kearifan Qur'ani anak-anak tahu dan paham Al-Qur'an dan Hadits, paham tentang arti pentingnya mengetahui dan memahami serta menerapkan dalam kehidupan sehari anak anak RA DWP IAIN Palu, mempraktekkannya walaupun belum semuanya tetapi para guru di RA tersebut secara bertahap memperkenalkan lewat penanaman nilai nilai karakter islam tersebut, minimal anak usia dini memahami dan mengetahui lebih dini atau lebih cepat tahu mengapa kita harus beribadah,berdoa, membaca barsanji, memaca azmaul husnah, membaca yasin,mengapa manusia harus di Aqikah, mengapa harus melakukan proses perkawinan dan akad nikah,mengapa perlu di sunat, mengapa perlu manusia ketika akhir baliknya diwajibkan menjalankan perintah Allah dan wajibnya setiap muslim, mengapa harus berhaji, berzakat, berkurban( kearifan Qur'ani), ketertarikan peneliti ingin mengetahui lebih dekat tentng tentang bagaimana bentuk penanaman nilai nilai karakter islam moderat di RA tersebut bagaimana bentuk moderasinya karna sebelumnya beberapa peneliti telah melakulkan penelitian terdahulu pada RA DWP IAIN mengangkat masalah pembelajaran motorik halus dan kasar anak, pembelajaran berbasis sentra dan masih banyak bentuk bentuk strategi dan pendekatan pembelajaran lainnya lainnya, namun dipenilitian ini peneliti mencobah meneliti dan mengamati bagaimana cara guru menanamkan nilai nilai karakter islam,factor apa saja yang menjadi daya dukung dan daya hambat bagi terlaksananya pembelajaran pada anak anak usia dini, serta sudah berimplikasikah terhadap pertumbuhan dan perkembangan anak khususnya anak anak yang bersekolah pada RA DWP IAIN Palu.

Pada kegiatan penanaman nilai nilai karakter dan kearifan pada anak anak usia dini merupakan hal yang sangat urgen adanya sebab, merupakan tanggungjawan kita bersama yang dalam kehidupan sehari hari anak akan tercermin pada sikap dan tingka laku anak dan cara menghadapi persoalan pribadinya penulis berpendapat pendidikan sebagai proses pencerdasan melalui pembelajaran sehingga guru dan orang tua harus bertanggungjawab untuk menjadikan seseorang tidak hanya sekedar mengenal nilai nilai kebaikan semata, melainkan dapat menyadarkan kepada anak untuk mengamalkan nilai nilai kebajikan tersebut dalam kehidupan sehari hari demi perwujudan karakter tangguh serta berkepribadian mulia.

Demikian pula tercantum dalam UU RI Nomor 20 tahun (2003) Bab 1 Pasal $1^{1}$, tentang sistem pendidikan nasional, bahwa pendidikan adalah usaha sadar dan terencana untuk mewujudkan suasana belajar dan proses pembelajaran agar peserrta didik secara aktif mengembangkan potensi dirinya, masyarakat, bangsa dan Negara UU RI Nomor 20 Tahun 2003 dan pendidikan anak usia dini harus berlandaskan pada kebutuhan anak, misalkan bagaimana cara guru menciptakan suasana system pembelajaran yang menarik dan menyenangkan dan guru harus mampu menciptakan

\footnotetext{
${ }^{1}$ Anwar Arifin, Memahami ParadigmaBaru Pendidikan Nasional dalam Undang-undang
} SISDIKNAS, (Cet;3, Jakarta:Ditjen Kelembagaan Agama Islam Depag, 2003), h. 34. 
situasi lingkungan pembelajaran yang kondusif, karna dengan metode belajar serta situasi belajar yang menarik dan menyenangkan anak,, anak akan bergairah dan senang untuk datang belajar dan bermain.

Kasmiati berpendapat ${ }^{2}$, bahwa Pendidijan anak usia dini merupakan salah satu tahapan pendidkan yang tidak dapat diabaikan karna ikut menentukan pertumbuhan dan perkembangan anak. Seiring pertumbuhan dan perkembangan jiwa anak dalam pembelajaran membutuhkan layanan atau bimbingan yang memadai khususnya anak anak usia dini di RA DWP IAIN Palu. Berdasar pada semua hal diatas penulis menetapkan pentingnya melakukan kajian uji analisis dan pengamatan melalui penelitian kualitatif dengan pendekatan studi kasus dengan pendekatan skala sikap dengan pijakan berfikir dan analisa dari konsep pembelajaran konstruktivisme dan system pembelajara among dengan menetapkan dengan mengacu pada judul penelitian ini" Penanaman nilai nilai karakter islam moderat melalui sosialisasi dan pembelajaran pada anak usia dini di RA DWP IAIN Palu".

\section{METODE PENELITIAN}

Metode penelitian yang digunakan adalah penelitian kualitatif dengan pendekatan penelitian tindakan kelas yang mendeskripsikan tentang proses implementasi penanaman nilai-nilai karakter Islam Moderat melalui sosialisasi dan pembelajaran pada anak usia dini. Subyek penelitian ini adalah anak di RA DWP IAIN Datokarama Palu yang berjumlah 11 anak laki laki dan 7 anak perempuan.

Pengumpulan data dilakukan dengan teknik observasi, wawancara dan dokumentasi. Teknik analisa data yang digunakan adalah reduksi data, penyajian data dan verifikasi data menggunakan skala penilaian indicator karakter dengan mengukur pada skala sikap BT (Belum Terlihat), MT (Mulai terlihat), MB (Mulai berkembang), MK (Sudah Menjadi Kebiasaan dan sudah Membudaya).

\section{HASIL DAN PEMBAHASAN}

\section{Pra Tindakan}

Penelitian dilaksanakan secara bersiklus yaitu siklus 1 dan 2 dengan melihat, mengamati nilai-nilai karakter pada aspek kesetaraan, Toleransi, Pembebasan, Kemanusiaan, Pluralisme, Sensitif, Non Diskrinminasi sampai dapat mencapai tingkat membudaya atau terbiasa dan dapat berkembang sesuai harapan. Namun sebelum peneliti melakukan tindakan penelitian, terlebih dahulu peneliti melakukan pra tindakan penelitian terlebih dahulu peneliti melakukan observasi awal untuk melihat sampai dimana kemampuan perkembangan, pengetahuan, sikap dan skill anak. Kegiatan pra tindakan, umumnya dilakukan sebelum peneliti memulai penelitian terhadap sikap karakter islam moderat sebagai berikut: 


\section{a. Penanaman Sikap Kesetaraan.}

Pada saat penanaman sikap kesetaraan guru menguraikan dan menyampaikan lewat metode ceramah, disampaikan bahwa ketika kita mau sholat duha dimulai semua anak anak berdiri dan bersiap dan perhatiakan shap masing masing dengan baik serta luruskan shafnya, ketika imam memimpin sholat anak anak tidak boleh saling mendahului, anak anak semuanya memiliki hak dan kewajiban yang sama mengikuti imam.memiliki kesetaraan atu kesedarajatan yang sama, khususnya ketika kita sholat berjamaah, anak anak tidak boleh berlomba lomba harus tertib demikian pula ketika kita belajar dan bermain dengan teman di sekolah maupun teman di rumah.

Dari hasil penelitian, diketahui bahwa dari 17 anak yang menjadi subyek penelitian, untuk kemampuan pengetahuan, sikap dan skill anak padaaspek Kesetaraan, terdapat 3 anak (15\%) yang dalam kategori sudah menjadi kebiasaan dan sudah membudayah (MB) karena anak sudah dapat mendengar dan melakukan perintah gurunya bahwa kita tidak boleh tidak berteman dan tidak boleh memilih milih teman semuanya sama, dalam 4 anak (25\%) dalam kategori berkembang sesuai harapan (MK) karena anak anak tersebut yang tadinya sulit menerima teman sudah mulai mau menerimah, dan ada 4 anak (25\%) yang mulai terlihat (MT) bisa menerima teman, indikatornya tadinya tidak menyapa sekarang sudah menyapa atau menegur miamenerimah temannya, sementara ada 6 anak (35\%) belum terlihat sikap mau menerimah teman yang berbeda (BT) berdiam indikatornya masih berdiam diri jika disapa oleh temannya yang dia anggap berbeda dengan dirinya

\section{b. Penanaman sikap Toleransi.}

Pada saat penanaman sikap Toleransi, guru menguraikan dan menyampaikan lewat metode ceramah, disampaikan bahwa ketika kita mau sholat dhuha, mau berdoa, belajar dan bermain dan berkarya semua anak anak dapat saling menerimah teman dengan baik dengan sesama teman, tanpa melihat agama dan keyakinan yang dianut oleh teman kita, kita wajib saling menghormati dan menghargai perbedaan anak anak semuanya memiliki hak dan kewajiban yang sama dalam bersekolah demikian pula dalam hal kita beragama, bersosial dan berbudayah kita harus dapat menciptakan prilaku bertoleransi antara satu pemeluk agama dengan pemeluk agama yang lain ketika kita sholat harus tertib demikian pula dalam belajar dan bermain dengan teman di sekolah maupun teman di rumah.

Dari hasil penelitian, diketahui dari 17 anak yang menjadi subyek penelitian, untuk kemampuan pengetahuan, sikap dan skill anak padaaspek Toleransi , terdapat 5 anak (20\%) yang dalam kategori sudah menjadi kebiasaan dan sudah membudayah (MB) karna anak sudah dapat mendengar dan melakukan perintah gurunya bahwa kita harus mebangun toleransi berteman dan tidak boleh memilih milih teman semuanya sama, dalam hal 5 anak (30\%) dalam kategori berkembang sesuai harapan (MK) karna anak anak tersebut yang tadinya sulit menerima teman sudah mulai mau menerima, dan ada 4 anak (30\%) yang mulai terlihat (MT)b isa menerima teman, indikatornya 
tadinya tidak menyapa sekarang sudah menyapa atau menegur miamenerimah temannya, sementara ada 3 anak (20\%) belum terlihat sikap mau menerimah teman yang berbedah (BT) indikatornya masih berdiam diri jika disapa oleh temannya yang dianggap berbeda dengan dirinya.

\section{c. Penanaman sikap Pembebasan}

Pada saat penanaman sikap Pembebasan guru meguraikan dan menyampaikan lewat metode ceramah, disampaikan bahwa ketika kita mau beraktifitas apa saja termasuk dalam belajar bermain, bernyanyi dan berkarya kita harus memberikan kebebasan teman teman kita untuk berkarya, menciptakan sesuatu karya atau kreasi, demikian pula ketika teman kita berpendapat atau memberi saran dan informasi kita dengar dengan baik siapa tau pesannya positif dan bermanfaat buat kita, anak anak intinya berilah kesempatan kepada teman untuk berpendapat, setiap anak punya hak yang sama sebagai warga negara, tidak boleh menekan kebebasan atau hak orang lain, ketika kita sholat berjamaah kita harus tertib tidak boleh saling mendahului demikian pula dalam belajar dan bermain dengan teman di sekolah demikian pula teman di luar sekolah (di rumah).

Dari hasil penelitian, diketahui dari 17 anak yang menjadi subyek penelitian, untuk kemampuan pengetahuan, sikap dan skill anak pada aspek Pembebasan, terdapat 2 anak (10\%) yang dalam kategori sudah menjadi kebiasaan dan sudah membudaya (MB) karena anak sudah dapat mendengar dan melakukan perintah gurunya bahwa kita harus membangun toleransi berteman dan tidak boleh memilih milih teman semuanya sama, dalam 4 anak (20\%) dalam kategori berkembang sesuai harapan (MK) karna anak anak tersebut yang tadinya sulit untuk bertoleransi sulit menerima teman sudah mulai bertoleransi, dan ada 5 anak (30\%) yang mulai terlihat (MT) bisa bertoleransi kepada teman dan mau menerima teman, indikatornya tadinya tidak bertoleransi sekarang sudah mulai bertoleransi atau menegur mianerimah temannya, sementara ada 6 anak (40\%) belum terlihat sikap mau bertoleransi menerimah teman yang berbeda (BT) berdiam indikatornya masih berdiam diri belum bertoleransi, belum membuka diri.

\section{d. Penanaman sikap Pluralisme}

Pada saat penanaman sikap Pluralisme, guru menguraikan dan menyampaikan lewat metode ceraman, disampaikan bahwa ketika kita mau sholat duha dimulai semua anak anak berdiri dan bershap dengan baik serta luruskan shafnya, ketika imam memimpin sholat anak anak tidak boleh saling mendahului, anak anak semuanya memiliki hak dan kewajiban yang sama mengitu imam.memiliki kesetaraan atu kesedarajatan yang sama, khususnya ketika kita sholat berjamaan, anak anak tidak boleh berlomba lomba tidak boleh saling mendahului, harus tertib demikian pula ketika belajar dan bermain dengan teman disekolah maupun teman di rumah.

Dari hasil penelitian, diketahui dari 17 anak yang menjadi subyek penelitian,

untuk kemampuan pengetahuan, sikap dan skill anak pada aspek Pluralisme, terdapat 
4 anak (25\%) yang dalam kategori sudah menjadi kebiasaan dan sudah membudayah (MB) karna anak sudah dapat mendengar dan melakukan perintah gurunya bahwa kita tidak boleh tidak berteman dan tidak boleh memilih milih teman semuanya sama, dalam 4 anak (25\%) dalam kategori berkembang sesuai harapan (MK) karna anak anak tersebut yang tadinya sulit menerima teman sudah mulai mau menerimah, dan ada 6 anak (30\%) yang mulai terlihat (MT) bisa menerima teman, indikatornya tadinya tidak menyapa sekarang sudah menyapa atau menegur mau menerimah temannya, sementara ada 3 anak (20\%) belum terlihat sikap mau menerimah teman yang berbedah (BT) indikatornya masih berdiam diri jika disapah oleh temannya yang dia anggap berbeda dengan dirinya.

\section{e. Penanaman sikap Kemanusiaan}

Pada saat penanaman sikap Kemanusiaan, guru menguraikan dan menyampaikan lewat metode ceraman, disampaikan bahwa ketika kita mau sholat dhuha dimulai semua anak anak berdiri dan bershap dengan baik serta luruskan shafnya, ketika imam memimpin sholat anak anak tidak boleh saling mendahului, anak anak semuanya memiliki hak dan kewajiban yang sama mengikuti imam. memiliki kesetaraan atu kesedarajatan yang sama, menghargai sesame,khususnya ketika kita sholat berjamaan, anak anak tidak boleh berlomba lomba harus tertib dalam melakukan sholat berjamaah demikian pula dalam belajar dan bermain dengan teman di sekolah maupun teman di rumah.

Dari hasil penelitian, diketahui dari 17 anak yang menjadi subyek penelitian, untuk kemampuan pengetahuan, sikap dan skill anak padaaspek Kemanusiaan, terdapat 3 anak (20\%) yang dalam kategori sudah menjadi kebiasaan dan sudah membudaya (MK) karena anak sudah dapat mendengar dan melakukan perintah gurunya bahwa kita tidak boleh tidak berteman dan tidak boleh memilih milih teman semuanya sama, dalam 4 anak (20\%) dalam kategori berkembang sesuai harapan (MB) karena anak-anak tersebut yang tadinya sulit menerima teman sudah mulamau menerimah, dan ada 5 anak (30\%) yang mulai terlihat (MT) bisa menerima teman, indikatornya tadinya tidak menyapa sekarang sudah menyapa atau menegur miamenerimah temannya, sementara ada 5 anak (30\%) belum terlihat sikap mau menerimah teman yang berbedah (BT) indikatornya masih berdiam diri jika disapa oleh temannya yang dia anggap berbeda dengan dirinya

\section{f. Penanaman Sikap Sensitif}

Pada saat penanaman sikap Sensitif, guru meguraikan dan menyampaikan lewat metode ceraman, disampaikan bahwa ketika kita mau sholat duha dimulai semua anak anak berdiri dan bershap dengan baik serta luruskan shafnya, ketika imam memimpin sholat anak anak tidak boleh saling mendahului, anak anak semuanya memiliki hak dan kewajiban yang sama mengitu imam. memiliki kesetaraan atau kesedarajatan yang sama, khususnya ketika kita sholat berjamaan, anak anak tidak boleh berlomba lomba, dapat memahami orang lain,peka terhadap situasi disekitar kita dan harus tertib dalam 
sholat berjamaah demikian pula ketika kita belajar dan bermain disekolah maupun di rumah.

Dari hasil penelitian, diketahui dari 17 anak yang menjadi subyek penelitian, untuk kemampuan pengetahuan, sikap dan skill anak pada aspek Sensitif, terdapat 3 anak (15\%) yang dalam kategori sudah menjadi kebiasaan dan sudah membudayah (MK) karna anak sudah dapat mendengar dan melakukan perintah gurunya bahwa kita tidak boleh tidak berteman dan tidak boleh memilih milih teman semuanya sama, dalam 4 anak (15\%) dalam kategori berkembang sesuai harapan (MB) karena anak anak tersebut yang tadinya sulit menerima teman sudah mulamau menerimah, dan ada 5 anak (35\%) yang mulai terlihat (MT) bisa menerima teman, indikatornya tadinya tidak menyapa sekarang sudah menyapa atau menegur miamenerimah temannya, sementara ada 5 anak (35\%) belum terlihat sikap mau menerimah teman yang berbedah (BT) erdiam indikatornya masih berdiam diri jika disapa oleh temannya yang dia anggap berbeda dengan dirinya.

\section{g. Penanaman Sikap Non Diskriminatif}

Pada saat penanaman sikap, Non Diskriminatif guru meguraikan dan menyampaikan lewat metode ceramah, disampaikan bahwa ketika kita mau sholat dhuha dimulai semua anak anak berdiri dan bersiap dengan baik serta luruskan shafnya, ketika imam memimpin sholat anak anak tidak boleh saling mendahului, anak anak semuanya memiliki hak dan kewajiban yang sama mengitu imam.memiliki kesetaraan atu kes edarajatan yang sama, khususnya ketika kita sholat berjamaan , anak anak tidak boleh berlomba lomba, kita semua punya hak dan kewajiban yang sama, tidak boleh kita saling membeda bedakan dan kita harus tertib dalam melaksanakan sholat berjamah demikian pula dalam belajar dan bermain disekolah maupun di rumah.

Dari hasil penelitian, diketahui dari 17 anak yang menjadi subyek penelitian, untuk kemampuan pengetahuan, sikap dan skill anak pada aspekn non diskriminasi, terdapat 2 anak (20\%) yang dalam kategori sudah menjadi kebiasaan dan sudah membudayah (MK) karena anak sudah dapat mendengar dan melakukan perintah gurunya bahwa kita tidak boleh tidak berteman dan tidak boleh memilih milih teman semuanya sama, dalam 4 anak (20\%) dalam kategori berkembang sesuai harapan (MB) karna anak anak tersebut yang tadinya sulit menerima teman sudah mulamau menerimah, dan ada 5 anak (30\%) yang mulai terlihat (MT) bisa menerima teman, indikatornya tadinya tidak menyapa sekarang sudah menyapa atau menegur menerimah temannya, sementara ada 6 anak (30\%) belum terlihat sikap mau menerimah teman yang berbedah (BT) indikatornya masih berdiam diri jika disapa oleh temannya yang dianggap berbeda dengan dirinya.

Berdasarkan rekapitulasi hasil pengamatan keseluruhan aspek, setelah dirataratakan ketujuh aspek sikap yang diamati terdapat terdapat 17,86\% dalam kategori sudah menjadi kebiasaan dan berbudaya (MK), 22,14\% dalam kategori mulai berkembang (MB), 30\% anak berkategori mulai terlihat (MT), dan 30\% anak yang 
kategori yang dihasilkan belum terlihat (BT). Setelah melihat hasil yang didapatkan dari pra tindakan ini, dapat terlihat hanya sebagian kecil anak yang memiliki kemampuan sudah menjadi kebiasaan dan sudah membudaya dengan simbol (MB) dan masih banyakmanak yang belum memiliki kemampuan pada aspek mulai berkembang, mulai terlihat dan masih banyak anak yang memiliki sikap pada kategori belum terlihat. Olehnya itu berdasarkan permasalahan tersebut diatas, maka peneliti melaksanakan penelitian tindakan kelas dengan maksud dan harapan dapat meningkatkan kemampuan perubahan prilaku sikap anak pada tujuh aspek nilai sikap setelah melakukan sosialisasi dan pembelajaran melalui implementasi penanaman nilai nilai karakter Islam moderat.

\section{Pengamatan Refleksi Tindakan Siklus 1}

Pada bagian tindakan siklus 1 ini, maka peneliti melakukan proses belajar berdasarkan RPPH yang telah dibuat dalam meningkatkan kemampuan pengetahuaan, sikap dan skill anak usia dini, pada siklus satu peneliti melakukan dua kali tindakan atau dua kali pertemuan dengan harapan agar dapat lebih meningkat.

Tabel 1. Refleksi Tindakan Siklus I Sosialisasi dan Pembelajaran

\begin{tabular}{|c|c|c|c|}
\hline No & Kelemahan & Analisis Penyebab & Rekomendasi \\
\hline 1 & $\begin{array}{l}\text { Kemampuan anak dalam } \\
\text { memahami nilai nilai } \\
\text { karakter Islam yang } \\
\text { dituturkan guru baik dalam } \\
\text { ucapan maupun perbuatan } \\
\text { dan gerak (tahu, cakap } \\
\text {,trampil) belum menjadi } \\
\text { keberkembang dengan baik }\end{array}$ & $\begin{array}{l}\text { Masih terbatasnya waktu } \\
\text { sosialisasi dan } \\
\text { pembelajaran nilai nilai } \\
\text { karakter islam, masih } \\
\text { terbatasnya kemampuan } \\
\text { guru mengelaborasi } \\
\text { pembelajaran } \\
\text { sebagaimana mestinya, } \\
\text { disebabkan anak anak } \\
\text { masih lebih senang } \\
\text { bermain, bernyanyi , } \\
\text { bercerita dan berdongeng, } \\
\text { masih kurang mau } \\
\text { mendengarkan pesan } \\
\text { pembelajaran dalam } \\
\text { bentuk,pengetahuan, nilai } \\
\text { dan pesan moral, kecuali } \\
\text { dibawa pesan tersebut } \\
\text { dalam belajar sambil } \\
\text { bermain. }\end{array}$ & $\begin{array}{l}\text { Membelajarkan } \\
\text { pengetahuan agama } \\
\text { tentang nilai, moral dan } \\
\text { karakter serta nilai nilai } \\
\text { kearifan lokal, sebaiknya } \\
\text { dilakukan dalam } \\
\text { pendekatan belajar sambil } \\
\text { bermain, demikian pula } \\
\text { dalam bercerita dan } \\
\text { berdongeng juga dalam } \\
\text { lagu dan bernyanyi dapat } \\
\text { diselipkan pesan pesan } \\
\text { moral dan nilai milai } \\
\text { karakter islam } \\
\text { didalamnya., } \\
\text { menyarankan kepada para } \\
\text { guru agar dapat } \\
\text { memperkayah khasanah } \\
\text { pembelajaran, khususnya } \\
\text { nilai nilai karakter Islam. }\end{array}$ \\
\hline 2 & $\begin{array}{l}\text { Partisipasi anak dalam } \\
\text { Sosialisasi } \\
\text { pembelajaran nilai nilai } \\
\text { karakter islam, belum } \\
\text { menjadi kebiasaan dan } \\
\text { belum membudayah }\end{array}$ & $\begin{array}{l}\text { Karakter bermain anak } \\
\text { berbeda dengan masa } \\
\text { sebelum bencana kata } \\
\text { guru, itu disebabkan, } \\
\text { banyak factor, jiwa } \\
\text { kemandirian anak, masih } \\
\text { ada terkadang muncul } \\
\text { rasa trauma untuk datang }\end{array}$ & $\begin{array}{l}\text { Guru sebaiknya merubah } \\
\text { model pendekatan dan } \\
\text { strategi belajar dan } \\
\text { bermain anak, } \\
\text { memberikan penguatan } \\
\text { terhadap anak arti } \\
\text { pentingnya bersekolah, } \\
\text { membangun komunikasi }\end{array}$ \\
\hline
\end{tabular}




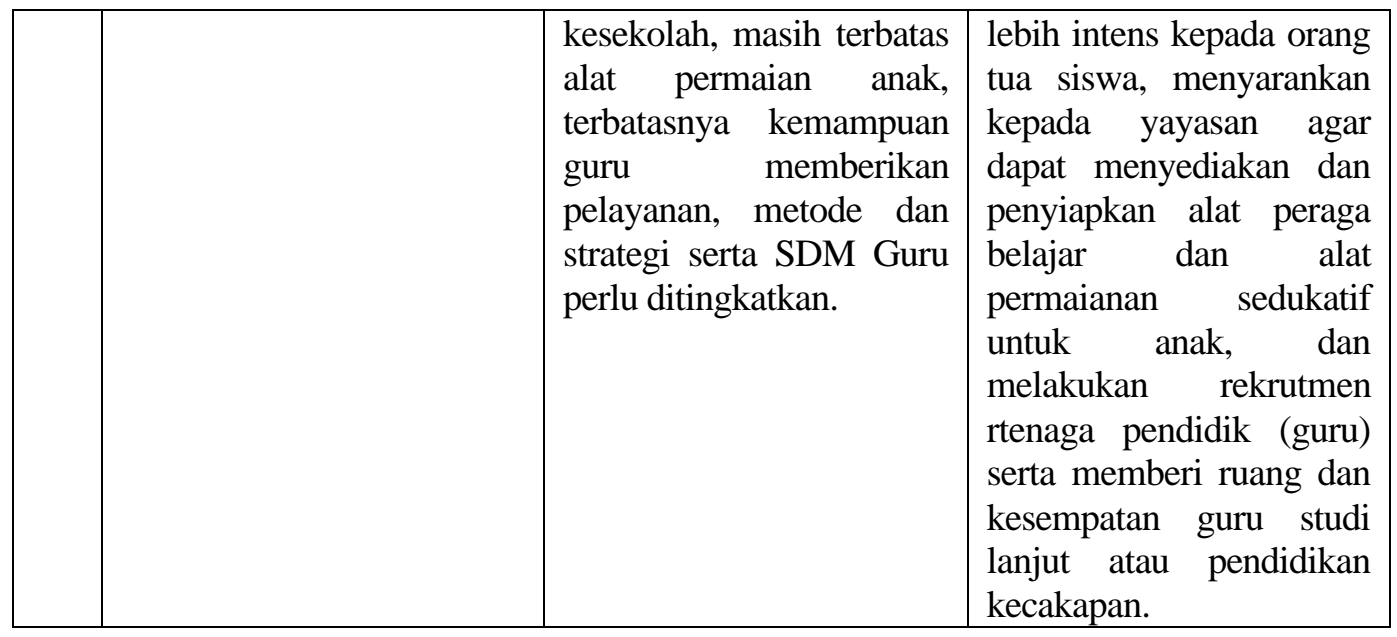

3. Penanaman Sikap Kesetaraan, Toleransi, Pembebasan, Pluralisme, Kemanusiaan, Sensitif, Diskriminasi

Pada aktiftas sosialisasi dan pembelajaran melalui implementasi penanaman nilai nilai karakter islam moderat, hal ini dilakukan dua kali pertemuan dikelas yang dimulai dengan membuat perencanaan, kemudian pelaksanaan dan melakukan observasi, saat pemberikan sosialisasi dan pembelajaran didampingi guru, dosen, mahasiswa sebagai pengamat.

a. Perencanaan

Pada perencanaan siklus 1 ini, dilakukan sebagai berikut:

1) Menetapkan tema dan tujuan pembelajaran ( nilai sikap )

2) Membuat rancangan program sosialisasi dan pembelajaran berdasarkan RPPH yang dibuat dan digunakan guru

3) Menyediakan media pembelajaran yang dibutuhkan

4) Membuat lembar observasi aktivitas guru

5) Membuat lebar penilaian peningkatan kemampuan pengetahuan ,ssikap dan skilll anak.

6) Membuat rubrik penilaian anak berkaitan peningkatan kemampuan anak.

\section{b. Pelaksanaan}

Pada pelaksanaan proses sosialisasi dan pembelajaran di dalam kelas berdasar pada RPPH yang telah tersedia, yaitu melakukan kegiatan pembuka selama 30 menit yang diawali dengan salam, setiap pembelajaran setiap hari sebelum pembelajaran berlangsung diawali dengan sholat dhuha 2 rakaat baru berdoa, kemudian dilanjutkan dengan berzikir dan kemudian stu persatu anak anak ada yang dituntun membaca surah surah pendek anak anak satu persatu bergantian secara teratur disebut nama oleh gurunya, setelah itmaksud dan tujuannya berdoa agar dalam proses belajar mengajar $\mathrm{u}$ mereka diminta guru membaca doa belajar, kemudian kegiatan selanjutnya. 
Melaksanakan kegiatan inti selama 60 menit. Dalam kegiatan inti, ada tujuh aspek satu persatu peneliti amati apakah ketujuh hal tersebut muncul atau tampak pada saat mulai anak di jemput oleh gurunya didepan pintu kemudian masuk kedalam kelas, kemudian anak anak d idudukkan dan diarahkan pada saat seholat dhuha berlangsung, sampai pada selesai anak anak membac surah surah pendek sampai pada tahap pembelajaran berlangsung, sambil menunggu waktu istirahat peneliti mengajak anak KE Taman Bermain di pekarangan sekolah mereka walaupun sempit area bermain anak anak RA DWP IAIN PALU sekarang ini ( pasca gempa ) namun anak anak tetap tetap ceria dalam bermain, penulis menarik kesimpulan sementara bahwa luas dan terbatasnya area bermain atau pekarangan sekolah anak anak RA DWP IAIN Datokarama Palu, tidak menyulutkan semangat mereka untuk datang belajar dan bermain di sekolah tersebut, tetapi bagaimana suasana lingkungan belajar yang menarik dan menyenangkan (kondusif) bagi anak anak juga orang orang yang mengitari anak anak dalam hal ini adalah kepala sekolah para guru demikian pula mahasiswa mahasiswi PIAUD Tarbiyah IAIN Datokarama Palu sesekali berada disekitar mereka, karna RA DWP IAIN Datokarama Palu merupakan laboratorium Prodi PIAUD. Setelah anak anak selesai bermain masuk kembali kedalam kelas kemudian melaksanakan kegiatn penutup pembelajarn selama 30 menit waktu berlangsung guru selalu mengingatkan ingat hafalan surah surah pendek, dan ingat baca doa belajar, doa makan dan doa sebelum tidur sebelum pulang guru memintah anak anaknya menyanyi lagu ceria sebelum pembelajaran ditutup dengan doa. Dan mengucapkan salam.

\section{Observasi}

Kegiatan observasi merupakan aktivitas dan kegiatan pembelajaran pada saat proses berlangsung dapat dilihat guru dan teman demikian pula oleh mahasiswa yang bertindak sebgai pengamat. Adapun hasil pengamatan aktivitas anak dalam pelaksanaan Siklus I dijelaskan sebagai berikut.

\section{a. Penanaman Sikap Kesetaraan.}

Pada saat penanaman sikap kesetaraan guru meguraikan dan menyampaikan lewat metode ceramah, disampaikan bahwa ketika kita mau sholat duha dimulai semua anak anak berdiri dan bersiap dan perhatiakan shap masing masing dengan baik serta luruskan shafnya, ketika imam memimpin sholat anak anak tidak boleh saling mendahului, anak anak semuanya memiliki hak dan kewajiban yang sama mengikuti imam.memiliki kesetaraan atu kesedarajatan yang sama, khususnya ketika kita sholat berjamaan, anak anak tidak boleh berlomba lomba harus tertib demikian pula ketika kita belajar dan bermain dengan teman di sekolah demikian pula di rumah.

Dari hasil penelitian, diketahui dari 17 anak yang menjadi subyek penelitian, untuk kemampuan pengetahuan, sikap dan skill anak pada aspek Kesetaraan, terdapat 5 anak (30\%) yang dalam kategori sudah menjadi kebiasaan dan sudah membudaya (MK) karena anak sudah dapat mendengar dan melakukan perintah gurunya bahwa 
kita tidak boleh tidak berteman dan tidak boleh memilih milih teman semuanya sama, dalam 5 anak (30\%) dalam kategori berkembang sesuai harapan (MB) karna anak anak tersebut yang tadinya sulit menerima teman sudah mulamau menerimah, dan ada 4 anak (30\%) yang mulai terlihat (MT) bisa menerima teman, indikatornya tadinya tidak menyapa sekarang sudah menyapa atau menegur miamenerimah temannya, sementara ada 3 anak (10\%) belum terlihat sikap mau menerimah teman yang berbeda (BT) berdiam indikatornya masih berdiam diri jika disapa oleh temannya yang dia anggap berbeda dengan dirinya.

\section{b. Penanaman sikap Toleransi}

Pada saat penanaman sikap Toleransi, guru meguraikan dan menyampaikan lewat metode ceramah, disampaikan bahwa ketika kita mau sholat dhuha, mau berdoa, belajar dan bermain dan berkarya semua anak anak dapat saling menerimah teman dengan baik dengan sesama teman, tanpa melihat agama dan keyakinan yang dianut oleh teman kita, kita wajib saling menghormati dan menghargai perbedaan anak anak semuanya memiliki hak dan kewajiban yang sama dalam bersekolah demikian pula dalam hal kita beragama, bersosial dan berbudaya kita harus dapat menciptakan prilaku bertoleransi antara satu pemeluk agama dengan pemeluk agama yang lain ketika kita sholat harus tertib demikian pula dalam belajar dan bermain dengan teman di sekolah demikian pula teman diluar sekolah (di rumah).

Dari hasil penelitian, diketahui dari 17 anak yang menjadi subyek penelitian, untuk kemampuan pengetahuan, sikap dan skill anak padaaspek Toleransi , terdapat 7 anak (40\%) yang dalam kategori sudah menjadi kebiasaan dan sudah membudayah (MK) karena anak sudah dapat mendengar dan melakukan perintah gurunya bahwa kita tidak boleh tidak berteman dan tidak boleh memilih milih teman semuanya sama, dalam 4 anak (25\%) dalam kategori berkembang sesuai harapan (MB) karna anak anak tersebut yang tadinya sulit menerima teman sudah mulamau menerimah, dan ada 4 anak (25\%) yang mulai terlihat (MT) bisa menerima teman, indikatornya tadinya tidak menyapa sekarang sudah menyapa atau menegur miamenerimah temannya, sementara ada 2 anak (10\%) belum terlihat sikap mau menerimah teman yang berbeda (BT) berdiam indikatornya masih berdiam diri jika disapa oleh temannya yang dia anggap berbeda dengan dirinya.

\section{c. Penanaman sikap Pembebasan}

Pada saat penanaman sikap Pembebasan guru meguraikan dan menyampaikan lewat metode ceramah, disampaikan bahwa ketika kita mau beraktifitas apa saja termasuk dalam belajar bermain, bernyanyi dan berkarya kita harus memberikan kebebasan teman teman kita untuk berkarya, menciptakan sesuatu karya atau kreasi, demikian pula ketika teman kita berpendapat atau memberi saran dan informasi kita dengar dengan baik siapa tau pesannya positif dan bermanfaat buat kita, anak anak intinya berilah kesempatan kepada teman untuk berpendapat, setiap anak punya hak yang sama sebagai warga negara, tidak boleh menekan kebebasan atau hak orang lain, 
ketika kita sholat berjamaah kita harus tertib tidak boleh saling mendahului demikian pula dalam belajar dan bermain disekolah demikian pula teman di rumah.

Dari hasil penelitian, diketahui dari 17 anak yang menjadi subyek penelitian, untuk kemampuan pengetahuan, sikap dan skill anak padaaspek Pembebasan, terdapat 4 anak (30\%) yang dalam kategori sudah menjadi kebiasaan dan sudah membudayah (MK) karena anak sudah dapat mendengar dan melakukan perintah gurunya bahwa kita tidak boleh tidak berteman dan tidak boleh memilih milih teman semuanya sama, dalam 5 anak (25\%) dalam kategori berkembang sesuai harapan (MB) karna anak anak tersebut yang tadinya sulit menerima teman sudah mulamau menerimah, dan ada 5 anak (25\%) yang mulai terlihat (MT) bisa menerima teman, indikatornya tadinya tidak menyapa sekarang sudah menyapa atau menegur miamenerimah temannya, sementara ada 3 anak (20\%) belum terlihat sikap mau menerimah teman yang berbeda (BT) berdiam indikatornya masih berdiam diri jika disapa oleh temannya yang dia anggap berbeda dengan dirinya.

\section{d. Penanaman Sikap Pluralisme.}

Pada saat penanaman sikap Pluralisme, guru menguraikan dan menyampaikan lewat metode ceramah, disampaikan bahwa ketika kita mau sholat dhuha dimulai semua anak anak berdiri dan bershap dengan baik serta luruskan shafnya, ketika imam memimpin sholat anak anak tidak boleh saling mendahului, anak anak semuanya memiliki hak dan kewajiban yang sama mengitu imam.memiliki kesetaraan atu kesedarajatan yang sama, khususnya ketika kita sholat berjamaah , anak anak tidak boleh berlomba lomba tidak boleh saling mendahului, harus tertib demikian pula ketika belajar dan bermain dengan teman di sekolah demikian pula teman di rumah.

Dari hasil penelitan, diketahui dari 17 anak yang menjadi subyek penelitian, untuk kemampuan pengetahuan, sikap dan skill anak pada aspek Pluralisme, terdapat 7 anak (40\%) yang dalam kategori sudah menjadi kebiasaan dan sudah membudayah (MK) karena anak sudah dapat mendengar dan melakukan perintah gurunya bahwa kita tidak boleh tidak berteman dan tidak boleh memilih milih teman semuanya sama, dalam 4 anak (25\%) dalam kategori berkembang sesuai harapan (MB) karena anak anak tersebut yang tadinya sulit menerima teman sudah mulai mau menerima, dan ada 4 anak (25\%) yang mulai terlihat (MT) bisa menerima teman, indikatornya tadinya tidak menyapa sekarang sudah menyapa atau menegur temannya, sementara ada 2 anak (10\%) belum terlihat sikap mau menerima teman yang berbeda (BT) indikatornya masih berdiam diri jika disapa oleh temannya yang dia anggap berbeda dengan dirinya.

\section{e. Penanaman Sikap Kemanusiaan}

Pada saat penanaman sikap Kemanusiaan, guru menguraikan dan menyampaikan lewat metode ceraman, disampaikan bahwa ketika kita mau sholat dhuha dimulai semua anak anak berdiri dan bershap dengan baik serta luruskan shafnya, ketika imam memimpin sholat anak anak tidak boleh saling mendahului, anak anak semuanya memiliki hak dan kewajiban yang sama mengikuti imam. memiliki 
kesetaraan atau kesedarajatan yang sama, menghargai sesama, khususnya ketika kita sholat berjamaan, anak anak tidak boleh berlomba lomba harus tertib dalam melakukan sholat demikian pula dalam belajar dan bermain dengan teman disekolah demikian pula teman diluar sekolah (di rumah).

Dari hasil penelitian, diketahui dari 17 anak yang menjadi subyek penelitian, untuk kemampuan pengetahuan, sikap dan skill anak padaaspek Kemanusiaan terdapat 5 anak (30\%) yang dalam kategori sudah menjadi kebiasaan dan sudah membudayah (MK) karena anak sudah dapat mendengar dan melakukan perintah gurunya bahwa kita tidak boleh tidak berteman dan tidak boleh memilih milih teman semuanya sama, dalam 5 anak (30\%) dalam kategori berkembang sesuai harapan (MB) karna anak anak tersebut yang tadinya sulit menerima teman sudah mulai mau menerimah, dan ada 4 anak (30\%) yang mulai terlihat (MT) bisa menerima teman, indikatornya tadinya tidak menyapa sekarang sudah menyapa atau menegur miamenerimah temannya, sementara ada 3 anak (10\%) belum terlihat sikap mau menerimah teman yang berbedah (BT) indikatornya masih berdiam diri jika disapa oleh temannya yang dia anggap berbeda dengan dirinya.

\section{f. Penanaman Sikap Sensitif}

Pada saat penanaman sikap Sensitif, guru menguraikan dan menyampaikan lewat metode ceraman, disampaikan bahwa ketika kita mau sholat dhuha dimulai semua anak anak berdiri dan bershap dengan baik serta luruskan shafnya, ketika imam memimpin sholat anak anak tidak boleh saling mendahului, anak anak semuanya memiliki hak dan kewajiban yang sama mengitu imam. memiliki kesetaraan atu kesedarajatan yang sama, khususnya ketika kita sholat berjamaan, anak-anak tidak boleh berlomba lomba, dapat memahami orang lain,peka terhadap situasi disekitar kita dan harus tertib dalam sholat demikian pula ketika kita belajar dan bermain dengan teman disekolah maupun teman di luar sekolah (di rumah).

Dari hasil penelitian, diketahui dari 17 anak yang menjadi subyek penelitian, untuk kemampuan pengetahuan, sikap dan skill anak pada aspek Sensitif, terdapat 6 anak (40\%) yang dalam kategori sudah menjadi kebiasaan dan sudah membudaya (MK) karena anak sudah dapat mendengar dan melakukan perintah gurunya bahwa kita tidak boleh tidak berteman dan tidak boleh memilih milih teman semua teman itu sama, dalam 6 anak (40\%) dalam kategori berkembang sesuai harapan (MB) karna anak anak tersebut yang tadinya sulit menerima teman sudah mulai mau menerimah, dan ada 3 anak (10\%) yang mulai terlihat (MT) bisa menerima teman, indikatornya tadinya tidak menyapa sekarang sudah menyapa atau menegur miamenerimah temannya, sementara ada 2 anak (10\%) belum terlihat sikap mau menerimah teman yang berbedah (BT) indikatornya masih berdiam diri jika disapa oleh temannya yang dia anggap berbeda dengan dirinya. 


\section{g. Penanaman Sikap Non Diskriminatif}

Pada saat penanaman sikap, Non Diskriminatif guru menguraikan dan menyampaikan lewat metode ceraman, disampaikan bahwa ketika kita mau sholat dhuha dimulai semua anak anak berdiri dan bersikap dengan baik serta luruskan shafnya, ketika imam memimpin sholat anak anak tidak boleh saling mendahului, anak anak semuanya memiliki hak dan kewajiban yang sama mengikuti imam.memiliki kesetaraan atu kesedarajatan yang sama, khususnya ketika kita sholat berjamaah, anak anak tidak boleh berlomba lomba, kata guru kita semua punya hak dan kewajiban yang sama, tidak boleh kita saling membeda bedakan dan kita harus tertib dalam melaksanakan sholat berjamah demikian pula dalam belajar dan bermain dengan teman disekolah maupun teman di luar sekolah (di rumah).

Dari hasil penelitian, diketahui dari 17 anak yang menjadi subyek penelitian, untuk kemampuan pengetahuan, sikap dan skill anak pada aspek Non Diskriminatif, terdapat 6 anak (30\%) yang dalam kategori sudah menjadi kebiasaan dan sudah membudayah (MK) karena anak sudah dapat mendengar dan melakukan perintah gurunya bahwa kita tidak boleh tidak berteman dan tidak boleh memilih milih teman semuanya sama, dalam 5 anak (30\%) dalam kategori berkembang sesuai harapan (MB) karna anak anak tersebut yang tadinya sulit menerima teman sudah mulai mau menerimah, dan ada 4 anak (30\%) yang mulai terlihat (MT) bisa menerima teman, indikatornya tadinya tidak menyapa sekarang sudah menyapa atau menegur menerimah temannya, sementara ada 2 anak (10\%) belum terlihat sikap mau menerimah teman yang berbedah (BT) indikatornya masih berdiam diri jika disapa oleh temannya yang dia anggap berbeda dengan dirinya.

Berdasarkan rekapitulasi hasil pengamatan pada siklus II, setelah dirata ratakan ketujuh aspek sikap yang diamati terdapat terdapat 34,29\% dalam kategori, sudah menjadi kebiasaan dan berbudaya (MK) 29,29 \% dalam kategori mulai berkembang (MB) $25 \%$ anak berkategori mulai terlihat (MT) 11,42\% anak yang kategori yang dihasilkan belum terlihat (BT).

Setelah melihat hasil yang didapatkan, dapat terlihat hanya sebahagian besar anak telah mengalami peningkatan perubahan yang memiliki kemampuan sudah menjadi kebiasaan dan sudah membudaya dengan simbol (MK) dan masih beberapa anak yang belum memiliki kemampuan pada aspek berkembang,menjadi kebiasaan dan berbudayah dan tidak ditemukan lagi anak yang belum terlihat kemampuan dan keinginan mau berubah. Olehnya itu berdasarkan permasalahan tersebut diatas, maka peneliti menyimpulkan bahwa pada dasrnya anak anak pada RA DWP IAIN Datokarama Palu, pada dasarnya memiliki sifat dan sikap karakter yang baik maksud dan harapan Peneliti dapat meningkatkan kemampuan perubahan prilaku sikap anak pada tujuh aspek nilai sikap setelah melakukan sosialisasi dan pembelajaran melalui implementasi penanaman nilai nilai karakter Islam moderat peneliti menarik kesimpulan bahwa sebahagian besar anak anak RA DWP IAIN Datokarama Palu, 
pada dasarnya sudah berkarakter baik, harapan semoga kedepan semakin baik dan meningkat mutu dan kualitas pembelajaran maupun jumlah peserta didiknya pada RA DWP IAIN Datokarama Palu, dimasa yang akan datang.

\section{Pengamatan Refleksi Tindakan Siklus II}

Pada bagian tindakan siklus II ini, maka peneliti melakukan proses belajar berdasarkan RPPH yang telah dibuat dalam meningkatkan kemampuan pengetahuaan, sikap dan skill anak usia dini, pada siklus satu peneliti melakukan dua kali tindakan atau dua kali pertemuan demikian pula pada siklus II dengan harpan agar dapat lebih meningkat, berdasarkan hasil temuan lapangan selama dua kali siklus hasil akhir mengalami penigkatan yang cukup signifikan.

Tabel 2. Refleksi Tindakan Siklus II

\begin{tabular}{|c|c|c|c|}
\hline No & Kelemahan & Analisis Penyebab & Rekomendasi \\
\hline 1 & $\begin{array}{l}\text { Kemampuan anak dalam } \\
\text { memahami nilai nilai } \\
\text { karakter Islam yang } \\
\text { dituturkan guru baik dalam } \\
\text { ucapan maupun perbuatan } \\
\text { dan gerak (tahu, cakap } \\
\text {,trampil) sudah mengalami } \\
\text { perkembangan meskipun } \\
\text { belum mencapai harapan } \\
\text { atau target yang diharapkan }\end{array}$ & $\begin{array}{l}\text { Masih terbatasnya waktu } \\
\text { sosialisasi dan } \\
\text { pembelajaran nilai nilai } \\
\text { karakter Islam, masih } \\
\text { terbatasnya kemampuan } \\
\text { guru mengelaborasi } \\
\text { pembelajaran } \\
\text { sebagaimana mestinya, } \\
\text { disebabkan anak anak } \\
\text { masih lebih senang } \\
\text { bermain, bernyanyi , } \\
\text { bercerita dan berdongeng, } \\
\text { masih kurang mau } \\
\text { mendengarkan pesan } \\
\text { pembelajaran dalam } \\
\text { bentuk, pengetahuan, nilai } \\
\text { dan pesan moral, kecuali } \\
\text { dibawa pesan tersebut } \\
\text { dalam belajar ambil } \\
\text { bermain.para tenaga } \\
\text { pendidik/guru masih perlu } \\
\text { peningkatan mutu dan } \\
\text { kualitas pembelajarannya. }\end{array}$ & $\begin{array}{l}\text { Membelajarkan } \\
\text { pengetahuan agama } \\
\text { tentang nilai, moral dan } \\
\text { karakter serta nilai nilai } \\
\text { kearifan lokal, sebaiknya } \\
\text { dilakukan dalam } \\
\text { pendekatan belajar sambil } \\
\text { bermain, demikian pula } \\
\text { dalam bercerita dan } \\
\text { berdongeng juga dalam } \\
\text { lagu dan bernyanyi dapat } \\
\text { diselipkan pesan pesan } \\
\text { moral dan nilai milai } \\
\text { karakter Islam } \\
\text { didalamnya., } \\
\text { menyarankan kepada para } \\
\text { guru agar dapat } \\
\text { memperkayah khasanah } \\
\text { pembelajaran, khususnya } \\
\text { nilai nilai karakter Islam } \\
\text { dan memvariasikan } \\
\text { metode pembelajaran } \\
\text { yang digunakan, sehingga } \\
\text { dapat menimbulkan minat } \\
\text { dan daya tarik anak untuk } \\
\text { belajar dan keingin tahuan } \\
\text { anak meningkat, sarana } \\
\text { prasarana belajar } \\
\text { mengajar dapat tersedia } \\
\text { sesuai pengembangan } \\
\text { bakat minat anak. }\end{array}$ \\
\hline 2 & $\begin{array}{lrr}\text { Partisipasi } & \text { anak } & \text { dalam } \\
\text { Sosialisasi } & & \text { dan } \\
\text { pembelajaran } & \text { nilai } & \text { nilai }\end{array}$ & $\begin{array}{lcc}\text { Karakter } & \text { bermain } & \text { anak } \\
\text { berbeda } & \text { dengan } & \text { masa } \\
\text { sebelum } & \text { bencana } & \text { kata }\end{array}$ & $\begin{array}{l}\text { Guru sebaiknya merubah } \\
\text { model pendekatan dan } \\
\text { strategi belajar dan }\end{array}$ \\
\hline
\end{tabular}




\begin{tabular}{|c|c|c|}
\hline $\begin{array}{l}\text { karakter Islam , Sudah } \\
\text { mulai menjadi } \\
\text { dan Subiasaan } \\
\text { perlahan } \\
\text { membudayah dikalangan } \\
\text { khususnya anak anak usia } \\
\text { dini di RA DWP IAIN } \\
\text { Datokarama Palu. }\end{array}$ & $\begin{array}{l}\text { guru, itu disebabkan, } \\
\text { banyak factor, jiwa } \\
\text { kemandirian anak, masih } \\
\text { ada terkadang muncul } \\
\text { rasa trauma untuk datang } \\
\text { kesekolah, masih terbatas } \\
\text { alat permaian anak, } \\
\text { terbatasnya kemampuan } \\
\text { guru memberikan } \\
\text { pelayanan, metode dan } \\
\text { strategi serta SDM Guru } \\
\text { perlu ditingkatkan dan } \\
\text { amatan peneliti perlahan } \\
\text { anak anak RA DWP IAIN } \\
\text { Datokarama palu } \\
\text { mengalami penigkatan } \\
\text { kualitas dan penyedaran } \\
\text { dan perubahan sikap dan } \\
\text { nilai nilai karakter Islam } \\
\text { yang terurai lewat } \\
\text { pembelajaran sudah mulai } \\
\text { mengalami peningkatan, } \\
\text { salah satu indikatornya } \\
\text { anak anak ketika peneliti } \\
\text { berkunjung pertama } \\
\text { sampai kunjungan ketujuh } \\
\text { sangat banyak perubahan } \\
\text { kemampuan, cara anak } \\
\text { anak bersikap, skill } \\
\text { bermain maupun } \\
\text { berkesenian meningkat } \\
\text { dan etika kesopanan juga } \\
\text { sangat membaik yang } \\
\text { dirasakan peneliti, namun } \\
\text { benar kata ibu guru SRI } \\
\text { DEWI, masih ada satu } \\
\text { dua ketika kesekolah ada } \\
\text { rasa takut, gelisa, diam } \\
\text { dan terkadang sedih, } \\
\text { namun sebahagian besar } \\
\text { sudah dapat dikategorikan } \\
\text { sudah menjadi kebiasaan } \\
\text { dan sudah membudaya }\end{array}$ & 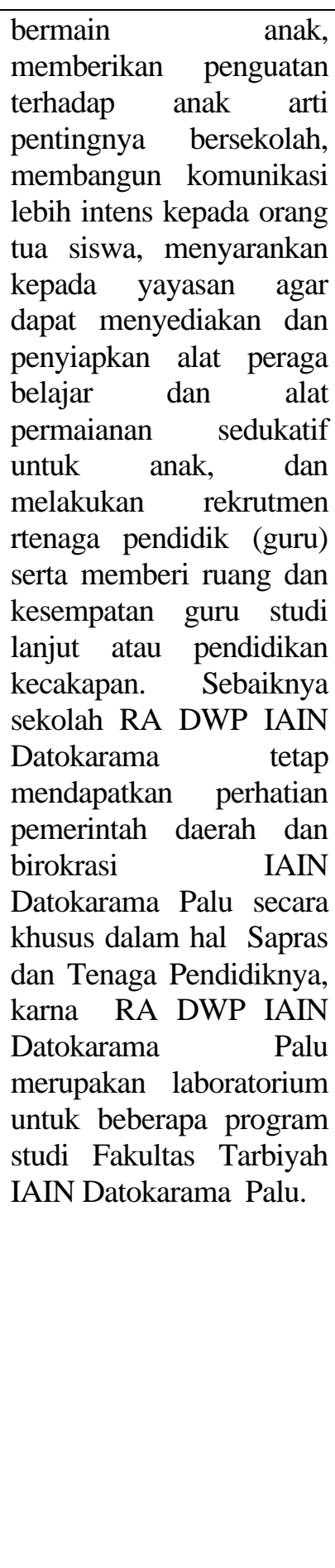 \\
\hline
\end{tabular}

6. Bagaimana Bentuk Implementasi Penanaman Nilai Nilai Karakter Islam Moderat Melalui Sosialisasi dan Pembelajaran di RA DWP IAIN Datokarama Palu

Bentuk penanaman nilai nilai karkter Islam moderat pada anak muslim moderat pada RA DWP IAIN Datokarama Palu dapat dilakukan melalui sosialisasi dan 
pembelajaran dengan bentukan variasi metode dan strategi dengan pendekatan pembelajaran konstruktivisme dan sistem pembelajaran Among, pembelajaran setiap harinya menurut amatan dan observasi peneliti setiap hari diawali dengan sholat dhuha, kemudian dilanjutkan mengaji dan menghafal surah surah pendek, menurut hasil wawancara penulis terhadap ibu kepala sekolah (ibu Namirah) dan dewan guru ibu,( Sri Dewi) bahwa aktifitas sholat dhuha dan mengaji serta menghafal surah surah pendek sudah merupakan jabaran kurikulum RA DWP IAIN, baru kemudian setelah itu dilanjutkan pembelajaran berbasis sentra, metode dan strategi yang lazim digunakan adalah, ceramah, berceritra, berdongeng, bernyanyi, berkarya/menganyam berkesenian, pasca gempa masih menyelesaikan satu pembelajaran pada satu sentra setiap hari, karna disamping pesrrta didiknya masih sedikit belum maksimal untuk dibagi pada beberapa sentra juga sarana prasarana dan lokasi pembelajaran masih terbatas/sempit implementasi penanaman nilai nilai karakter Islam moderat dalam rangka pembentukan pengetahuan, sikap dan keterampilan /skill pada anak usia dini dapat diberikan sedini mungkin sehingga dapat berdampak sistemik pada tumbuh kembang anak dan ini merupakan suatu bentuk upaya pembentukan dan pembinaan yang ditujukan kepada anak sejak lahir sampai usia enam tahun, sebab pada rentang usia ini secara terminologi disebut Masa golden age. Anak masa pra sekolah, dalam artian pada usia seperti itu pendidikan sudah mulai ditanamkan dalam rangka perkembangan tingkat kecerdasan anak, yang dimana dalam penelitian ini, peneliti temukan mengalami peningkatan dari siklus I, ke siklus II mengalami peningkatan yang signifikan dimana pada indicator peserta didik sudah menjadi kibiasaan dan sudah membudayah (MK) 17,86\% - 34,29\%, dan pada indicator peserta didik mulai berkembang (MB) 22,14\%-24,29\%, sementara pada indicator peserta didik mulai terlihat perkembangannya (MT) 30\%-25\%, demikian pula pada indicator peserta didik belum terihat adanya perkembangan (BT) 30\%-11,4\%.

Program Pendidikan Anak Pra sekolah atau Anak Usia Dini (PAUD) yang sudah direalisasikan pemerintah dalam bentuk pendidikan in formal, formal dan non formal. Salah satu bentuk program pendidikan anak usia dini yang kita kenal adalah Raudathul Atfhal (RA) dan Taman Kanak-kanak(TK). Taman Kanak-kanak merupakan bentuk satuan pendidikan anak usia dini pada jalur pendidikan formal yang menyelenggarakan program pendidikan bagi anak usia empat tahun hingga enam tahun. Selain itu, Raudhatul Athfal juga merupakan satuan pendidikan anak usia dini pada jalur pendidikan formal yang menyelenggarakan program pendidikan umum dan pendidikan keagamaan Islam bagi anak berusia empat sampai enam tahun.

Pelaksanaan pembelajaran dalam rangka pembentukan dan pembinaan anak usia dini dengan menanamkan sifat/ sikap karakter pada tujuh aspek yang menjadi bahasan peneliti pada aspek bagaimana dari peserta didik (anak usia dini) diajar didikkan tentang bagaimana membangun hidup kesejajaran, hidup berdampingan secara damai dengan sesama teman, ibu bapak guru, orang tua di rumah. Aspek bagaimana peserta 
didik ( anak usia dini) tahu dan paham tentang bagaimana saling menghargai dan menghormati teman, ibu bapak guru, orang tua dan orang lain Aspek bagaimana peserta didik tahu tentang bagaimana berempati, memiliki kepekaan dan kepedulian sesama teman dan orang lain. Peserta didik( anak usia dini) diajar didikkan bagaimana menghargai dan menghormati kemanusian atau eksistensi setiap individu sesama ciptaan Tuhan (Allah). Peserta didik diajar didikkan bagaimana menghargai kebebasan dan hak setiap orang atau teman dan orang lain. Peserta didik tahu setelah diajar didikkan tentang memberi perlakuan kepada teman dan orang lain yang tidak membeda bedakan,yang biasa disebut non diskriminatif, dalam rangka menstimulus berbagai aspek perkembangan memerlukan penanganan dengan memberikan penguatan kepada peserta didik (anak usia dini) arti pentingnya orang lain pada eksistensi arti keberadaan dalam hidup kita di muka bumi sebagai Sunnahtullah yang wajib kita hargai dan pedomani dalam hidup. Sebagaimana dipertegas oleh Menurut Patimah (2011) pendidikan karakter secara terintegrasi melalui sosialisasi dan pembelajaran adalah pengenalan nilai-nilai dan diperolehnya kesadaran akan pentingnya nilai-nilai, dan penginternalisasian nilai-nilai ke dalam tingkah laku peserta didik sehari hari melalui proses pembelajaran baik yang berlangsung di dalam maupun di luar kelas yang terintegrasi dan terimplementasi pada mata pelajaran dan metode metode dan strategi serta pendekatan belajar dan pembelajaran peserta didik ( anak usia dini). ${ }^{3}$

Sementara pendidikan karakter menurut,Narwanti adalah segala sesuatu yang dilakukan guru yang mampu mempengaruhi karakter peserta didik, melalui penanaman nilai nilai karakter Islam guru dapat membantu membentuk kepribadian peserta didik.keteladanan perilaku dan cara guru menyampaikan materi, cara guru bertoleransi, dan berbagai hal terkait lainnya. ${ }^{4}$ Karakter merupakan watak, tabiat, akhlak, atau kepribadian seseorang yang terbentuk dari hasil internalisasi berbagai kebajikan (virtues) yang digunakan sebagai landasan untuk cara pandang, berpikir, bersikap, dan bertindak. Kebajikan terdiri atas sejumlah nilai, moral, dan norma, seperti jujur, berani bertindak, dapat dipercaya, dan hormat kepada orang lain dan kese,uamya itu, adalah bagian dari nilai nilai karakter. Demikian pula menurut hasil penelitian dibidang neurologi seperti yang dilakukan oleh Dr.Benyamin S. Bloom, seorang ahli pendidikan dari universitas Chicago, amerika serikat, mengemukakan bahwa pertumbuhan sel jaringan otak pada anak usia 0-4 mencapai $50 \%$. Artinya bila usia tersebut otak anak mendapatkan rangsangan yang maksimal maka orang tidak akan berkembang secara optimal.juga pandangan Bailor collage of Medicine menyatakan

${ }^{3}$ Patimah. 2011. "Pendidikan Karakter Secara Terpadu Dalam Pembelajaran ." Publish : 18-102011 23:23:03. http//www.patimah/characterbuild/html. Diakses tanggal 21 Januari 2012.

${ }^{4}$ Narwanti, Sri. 2011. Pendidikan Karakter. Yogyakarta: Familia. 
bahwa lingkungan juga memberii peran yang sangat besar dalam pembentukan sikap, karakter, kepribadian dan pengembamngan kemampuan secara optimal.

\section{Faktor Pendukung dan Faktor Penghambat Implementasi Penanaman Nilai-Nilai Karakter Islam Moderat Melalui Sosialisasi dan pembelajaran di RA DWP IAIN Datokarama Palu}

Adapun yang menjadi factor pendukung terwujud dan terlaksananya lembaga pendidikan RA DWP IAIN Datokarama Palu itu dikarenakan lembaga pendidikan kepaudan (PAUD) ini merupakan bagian integral dari IAIN Datokarama Palu, kehadiran RA/TK ini ditengah kampus IAIN Datokarama Palu, juga memberi kontribusi besar terhadap pertumbuhan dan perkembangan kampus IAIN Datokarama Palu dewasa ini, karna juga dapat menginspirasi para mahasdiswa calon guru, khususnya mahasiswa Tarbiyah lebih khusus lagi pemilik Laboratorium yaitu Prodi PIAUD Fakultas Tarbiyah, karna pada dasarnya Pendidikan anak usia dini tidak hanya sekedar berfungsi untuk memberikan pengalaman belajar kepada peserta didik tetapi juga memiliki fungsi yang lebih penting lagi yaitu RA/TK, dapat untuk mengoptimalkan perkembangan otak atau intelegensi peserta didik ( anak usia dini) demikian pula RA DWP IAIN Datokarama Palu secara khusus dan IAIN Datokarama Palu dapat menjadi agen pembaharu dalam pengembangan pendidikan khususnya pendidikan Islam di Sulawesi tengah.

Pada hakekatnya pendidikan harus mampu meningkatkan basic knowledge (pengetahuan dasar) Intelectual dan manual skill (keterampilan manual intelektual) dan intelektual power of rareason critism (daya nalar/kritik), Value, attitudes and motivation (nilai-nilai sikap dan motivasi), Power of creativity and Innovation (daya kritik dan inovasi), cultural aprseasen (apresoiasi kebudayaan), sense of social responsibily (tanggungjawab sosial) dan Understending of the modern wold (memahami dunia modern) dan bagaimana menjadi bangsa ini sebagai bagian dari wargamasyarakat dan sekaligus sebagai warga dunia (Nation for state). Hal ini harus terwujud pada lembaga IAIN Datokarama Palu dimasa yang akan datang, sebab ditopang sarana prasarana yang cukup memadai dan situasi kampus perlahan dikatakan sudah aman dan nyaman ditempati bersekolah atau berpendidikan lingkungannya sudah kondusif.

Adapun yang menjadi factor penghambat pengembangan kapasitas sapras dan SDM demikian pula tingkat partisifasi peminat orang tua atau masyarakat menyekolahkan putra putrinya pada RA DWP IAIN Datokarama Palu, akhir setahun setelah pasca gempa bumi dan tsunami melanda Kota Palu dan sekitarnya, salah satu factor penghambat namun tidak menjadikan sekolah atau lembaga pendidikan RA DWP IAIN Datokarama Palu tidak berkembang,namun justru setelah gempa bumi melanda kota palu disatu sisi membawa malapetaka tapi dilain sisi membawa keberkahan dimana setelah gempa bumi terjadi, terjadinya peningkatan pengembangan perkotaan dan kependudukan, berkembangan sarana perekonomian 
khususnya pedagang kaki lima, tigginya antusias masyarakat muslim khususnya pada kegiatan keagamaan baik ditingkat anak, remaja demikian pula pada tingkatan orang tua atau tokoh agama dan tokoh adat (TOGAMA DAN TOADA) level ketokohan, tingginya rasa kesadaran rasa memiliki atau berbagi ( bersedekah) itu juga meningkat. meningkatnya kesadaran masyarakat Kota Palu dan sekitarnya menyekolahkan anaknya pada sekolah atau lembaga pendidikan yang bermisikan pendidikan Agama pada lembaga pendidikan di bawah Kementerian Agama mulai pada tingkat pendidikann dasar sampai perguruan tinggi salah satu indikatornya IAIN Datokarama Palu mengalami peningkatan peminat calon mahasiswa setiap tahun, jadi penulis berpendapat bahwa perkembangan RA DWP IAIN Datokarama Palu akan semakin berkembang seiring terjadinya perkembangan dan kemajuan IAIN Datokarama Palu.

\section{KESIMPULAN}

Berdasarkan analisa data hasil pembahasan, dapat disimpulkan bahwa melalui sosialisasi dan pembelajaran, implementasi penanaman nilai nilai karakter Islam moderat pada anak usia dini di RA DWP IAIN Palu, peneliti dapat menyimpulkan pencapaian perubahan sikap pada aspek kemampuan pengetahuan, aspek sikap dan keterampilan/skill anak. Peningkatan pengetahuan, sikap dan keterampilan/skill anak melalui Implementasi penanaman nilai nilai karakter Islam moderat pada anak usia dini di RA DWP IAIN Datokarama Palu mengalami peningkatan dari siklus I ke siklus II, pada kategori masing masing aspek Menjadi kebiasaan dan membudaya (MK), Mulai berkembang (MB), Mulai Terlihat (MT), dan Belum terlihat (BT).

Setelah dilaksanakan tindakan dengan menggunakan metode pembelajaran dalam belajar dalam bentuk berdoa, bermain, bernyanyi, berdongeng, dan berkarya (menganyam) dengan pendekatan pembelajaran konstruktivisme dan pendekatan pembelajaran sistem Among pada siklus I, kemampuan pengetahuan, sikap dan keterampilan/skill anak, belum sesuai harapan terwujudnya anak dengan pola sikap "Sudah menjadi kebiasaan sudah membudaya" belum mencapai $70 \%$ dari 7 (tujuh indikator sikap karakter Islam moderat) yang diujikan melalui penelitian ini, dengan memperbaiki semua kelemahan di siklus I, dan II, kemudian hasil pengamatan dan hasil temuan pada siklus menunjukkan peningkatan yang baik pada aspek sikap anak sudah menjadi kebiasaan dan sudah membudayah pada kategori (MK) 17,86\% menjadi 34,29 \%, pada aspek sikap anak mulai berkembang pada kategori (MB) 22,14\% menjadi 24,29\%, pada aspek sikap anak sudah mulai terlihat pada kategori (MT) $30 \%$ menjadi $25 \%$, pada aspek sikap anak belum terlihat pada kategori (BT) $30 \%$ menjadi $11,4 \%$. 


\section{SARAN}

Berdasarkan kesimpulan penelitian ini, ada beberapa saran yang dapat dikemukakan oleh peneliti bagi:

1. Anak

Diharapkan kepada anak usia dini agar selalu aktif dalam kegiatan kelas, dapat mengerjakan tugas yang diberikan guru, memanfaatkan fasilitas yang ada untuk mengembangkan semua potensi atau kemampuan yang dimiliki menjadi sebuah kompetensi .

2. Guru

Diharapkan para guru dalam melaksanakan implementasi penanaman nilai nilai karakter anak dalam melakukan menjabarkan nilai nilai karakter Islam moderat dapat membentuk perubahan pola pikir, pola sikap dan pola tindak pada diri anak usia dini.

3. Kepada kepala RA/PAUD

Diharapkan dapat memberi kebijakan para guru dalam rangka peningkatan kualitas( studi lanjut)

4. Peneliti

Diharapkan produk dari penelitian ini dapat dijadikan sebagai bahan banding, bahan acuan dalam merancang suatu pembelajaran demikian pula penelitian sejenis dalam hal ini penelitian tindakan kelas

\section{DAFTAR PUSTAKA}

Anwar Arifin, Memahami Paradigma Baru Pendidikan Nasional dalam Undangundang SISDIKNAS, (Cet. 3, Jakarta : Ditjen Kelembagaan Agama Islam Depag, 2003).

Kasmiati, Hasil Penelitian IAIN Datokarama Palu. (LP2M, 2018).

Narwanti Sri, Pendidikan Karakter. (Yogyakarta: Familia, 2011)

Patimah, "Pendidikan Karakter Secara Terpadu Dalam Pembelajaran ." Publish : 1810-2011 23:23:03. http//www.patimah/characterbuild/html. Diakses tanggal 21 Januari 2018. 